\title{
SSynthesis
}

International Scientific Conference of IT and Business-Related Research

\section{ESP COURSE DESIGN FOR THE 21ST CENTURY: TEAM TEACHING AND HYBRID LEARNING}

\author{
KURS ENGLESKOG JEZIKA ZA POSEBNE NAMENE U XXI VEKU: \\ TIMSKA NASTAVA I HIBRIDNO UČENJE
}

\author{
Dragana Spasić ${ }^{1}$, Anita Janković ${ }^{1}$, Milica Spasić-Stojković ${ }^{2}$ \\ ${ }^{1}$ Faculty of Philosophy, KosovskaMitrovica, Serbia \\ ${ }^{2}$ Business School of Applied Studies, Blace, Serbia
}

\begin{abstract}
:
This paper aims to promote higher foreign language competences in both students and academic staff by implementing hybrid learning approach and team-teaching strategy in ESP course design. Teamteaching of a language teacher and a content instructor contributes to the direct and practical use of the language in the context of the study field, which in turn further enhances the learning experience. In addition, in hybrid learning, each delivery mode serves as a tool allowing for differentiated instruction and successful task completion. Firstly, the paper will review relevant theory and research literature discussing the benefits and drawbacks of interdisciplinary team teaching strategy. Secondly, it will outline a hybrid course of English for Computer Programming demonstrating how hybrid learning and teamteaching can be used as a basis for ESP university courses. Furthermore, it will tackle unified learning outcomes and assessment, and present a virtual classroom where the language and content intertwine. The prospective course is designed to be delivered at the Business School of Applied Studies in Blace and the University of Priština's Centre for Training and Development in Kosovska Mitrovica.
\end{abstract}

\section{Key words:}

English for Specific Purposes, interdisciplinary team teaching, hybrid learning, Content and Language Integrated Learning.

"Instructional roles are so diverse and require such different mixes of tasks, talents, and temperaments that the smaller parts must be played by more than one person."

James L. Bess (2000)

\section{INTRODUCTION}

Teaching a foreign language for specific purposes (FSP) is "always of paramount importance in all educational contexts" (Kaur, 2007). Our students as future professionals depend on proficient foreign language skills; knowing a foreign language specific to their study field increases their employability and mobility. Higher Education Ministers within the European Commission have established that the development of professional competences, including foreign language skills, is the primary objective of the 21st century universities (Communiqué, 2009). The main issue with FSP course design is that the mechanics are not flat; simply determining the aim through needs analysis and matching it to the method to attain it. Furthermore, as Anthony identified, in FSP there is "a still unresolved discussion on whether the language teacher should be an expert in the target subject of the class" (2007).

\section{Apstrakt:}

Ovaj rad ima za cilj da promoviše veće jezičke kompetencije kod studenata i nastavnog osoblja kroz primenu hibridnog pristupa u učenju i strategije timske nastave u izradi i realizaciji kurseva engleskog jezika za posebne namene.Timski rad nastavnika jezika i poznavaoca stručnih termina u nastavi vodi ka direktnoj i praktičnoj upotrebi jezika u datoj oblasti, što zauzvrat unaprešuje kvalitet samog procesa učenja. Takođe, kod hibridnog učenja, svaki vid isporuke može se posmatrati kao sredstvo koje doprinosi raznolikosti samog procesa nastave i uspešnoj realizaciji zadatih ciljeva.

$\mathrm{Na}$ samom početku ćemo se pozabaviti relevantnim teorijama i stručnom literaturom koja se bavi prednostima i nedostacima strategije interdispilinarnog timskog učenja. Nakon toga, daje se prikaz hibridnog kursa iz engleskog jezika u oblasti kompjuterskog programiranja koje pokazuje kako hibridno učenje i timska nastava zajedno mogu predstavljati osnovu za izradu kurseva jezika za posebne namene na univerzitetima. Osim toga, rad se bavi jedinstvenim ishodima učenja i procene, i nudi prikaz virtuelne učionice u kojoj se prepliću jezik i sadržaj. Potencijalni kurs je dizajniran za potrebe Poslovne škole strukovnih studija u Blacu i Centra za obuku i razvoj u Kosovskoj Mitrovici, Univerziteta u Prištini.

\section{Ključne reči:}

engleski kao jezik struke, interdisciplinarna timska nastava, hibridno učenje, integrisano učenje sadržaja i jezika.

This paper aims to promote higher foreign language competences in both students and academic staff by implementing hybrid learning approach and team-teaching strategy. Firstly, the paper will review relevant theory and research literature discussing the benefits and drawbacks of interdisciplinary team teaching. Secondly, it will outline an integrative course of English for Computer Programming demonstrating how hybrid learning and team-teaching combined can be used as a basis for FSP university courses. Furthermore, it will tackle unified learning outcomes and assessment, as well as present a virtual classroom where the language and content intertwine.

\section{ESP COURSE DESIGN AND TEACHER COMPETENCES}

Dudley-Evans (1998) outlines absolute and variable characteristics of English for specific purposes (ESP). The absolutes denote a course which: a) caters for learners' needs; b) employs methodology characteristic for the study field it serves; and c) pivots on language elements appropriate for the study field. On the other hand, it is assumed that the course is designed for a specific discipline, mainly for adult learners at the tertiary level 
who are at the intermediate or advanced level with the basic grasp of the language system. In other words, ESP is studentcentered language learning in synergy with a particular content subject or study field. However, several practical concerns arise from these characteristics (Nunan, 1987). Firstly, Nunan argues that every ESP course should promote communication competences in professional settings. This could be achieved by even distribution of specific and general language learning. Furthermore, the author points out that the course materials should be easily adaptable and constantly developed.

Secondly, a single most important concern in the ESP course design is the teacher (content, professional) knowledge. The concept of teacher knowledge is three-dimensional; the primary element is the cognition of the target language, its system, and specific discourse; secondly, a teacher's grasp of the academic discipline which the ESP serves; and finally, cognition of the foreign language methodology and theories of learning (GórskaPoręcka, 2013). A teacher would gain the theoretical knowledge in the academic context, but more importantly performance skills are gained through work experience and professional development. The specialist knowledge has been a stumbling block of ESP; teacher competences have often been questioned and doubted due to the lack of understanding of the content subjects. Bell reports the opinion that an ESP teacher could not teach the particular language context without understanding the study field, moreover, without having deep insights into the field (2002). Therefore, the peculiarities of the ESP would be lost to such a teacher.

\section{INTERDISCIPLINARY TEAM TEACHING}

One possible solution to the concerns expressed in the previous section is the introduction of interdisciplinary team teaching ESP courses. Buckley states that the foremost argument in favor of curriculum integration is "the disconnection between a discipline-based curriculum and the real world" (2000). In addition, Barron emphasizes that "cognitive and communicative competences cannot be separated" (1992). Consequently, to empower ESP teachers in ensuring that language and academic skills are developed simultaneously they should be paired up with subject specialists. Selinker calls them "informants" and proceeds with sarcasm when saying that they provide "the naive ESP teacher" with insights on the content and the organization of texts and on the processes of their subject (1979). Nevertheless, Barron proposes three methods of cooperation that fit the framework of this paper. However, we will firstly define team teaching and provide arguments and evidence gathered from the survey of relevant theory and research literature supporting the value of this strategy.

Team teaching, parallel teaching, supportive or complementary teaching, collaborative teaching, co-teaching, these are just several names for one and the same strategy where two or more teachers work together with the same aim for the same group of students. Additionally, Buckley supplements this definition with determiners such as "purposefully, regularly, and cooperatively" (2000). There are two categories differentiated by whether the teaching team shares the physical space (the classroom) or not. True team teaching involves ESP teacher and subject specialist co-operating fully throughout the course, delivering instruction simultaneously in the same classroom (Barron, 1992; Dinitz et al., 1997). In similar fashion, Conderman and McCarty define it as a strategy where a "group of teachers work together, plan, conduct, and evaluate the learning activities for the same group of students" (2003). For the purpose of this paper, we adopt the term team teaching as defined by Buckley who describes two teachers who bring to the table their "distinct and complementary sets of skills, combine roles and share resources and responsibilities in a sustained effort while working towards the common goal of academic success" (2000).

There are many considerations to be made to ensure the success of this strategy. Little and Hoel emphasize the importance of careful selection of the teaching partner. Furthermore, they warn the teachers to manage their expectations as well as to ask themselves whether they can "remain open-minded, share control, and not become easily offended" (2011). Stewart and Perry recommend committing to the practice of reflective teaching and being open to share and accept what others offer (2005). Finally, Leavitt reports a mock Decalogue of two Stanford University professors who summed up the rules for a successful teaching team (2006):

1. Thou shalt plan everything with thy neighbor.

2. Thou shalt attend thy neighbor's lectures.

3. Thou shalt refer to thy neighbor's ideas.

4. Thou shalt model debate with thy neighbor.

5. Thou shalt have something to say, even when thou art not in charge.

6. Thou shalt apply common grading standards.

7. Thou shalt ask open questions.

8. Thou shalt let thy students speak.

9. Thou shalt attend all staff meetings.

10. Thou shalt be willing to be surprised.

Research literature indicates that once the conditions are right, team teaching has numerous student, teacher, and professional benefits. The most general and far-fetching benefit of the presence of the interdisciplinary faculty member is that it "reinforces the importance of alternative viewpoints and perspectives" (Little \&Hoel, 2011). Similarly, Fenollera et al. state that team teaching provides multiple learning perspectives and promotes teamwork and communication between teachers and students (2012). In addition, Leavitt points out that it provides instructors with "a useful way of modeling thinking within or across disciplines" (2006).

Conderman and McCarty believe that by pooling the resources, materials, experiences, and strengths, the classroom experience is richer than if the course had been taught independently; teachers benefit from "the spirit of parity" where both sides are equally valued and have executive power (2003). Buckley reinforces this notion by suggesting that teachers express parity by playing "the dual roles of teacher and learner, expert and novice, giver and recipient of knowledge or skills" (2000). Finally, professional benefits spring from the concept of teacher knowledge (Górska-Poręcka, 2013) where the fourth dimension is added, and it refers to cognition of one's own behaviour and habits.

As previously mentioned, Barron devised three types of interaction in team teaching (1992). They range from the least involvement of the specialist to the full integration of the disciplines. The first is the consultative method where the subject specialist is brought into advice in certain stages of the course delivery. Secondly, there is the collaborative method in which the teaching team works together on all course aspects except for the shares the classroom. Finally, the intervention method implies teaching in a shared physical space. In view of our proposed model course, we opted for the combination of the second and the third method as our teaching team does not share the brick-and-mortar classroom, but they do deliver the joint instruction in the virtual learning environment. 


\section{THE MODEL ESP COURSE}

The Business School of Applied Studies in Blace comprises the following study programmes: Computing and Informatics, Finance and Accounting, Taxes and Customs, Management and International Business Administration, and Tourism. All students are required to take English language courses throughout the three years of their BA studies. Due to various organizational requirements, students of two, or even three study programs used to attend English classes together. Therefore, a general business English course was selected to try to accommodate the professional needs of all of them, as well as various levels of their language competences.

However, this represented a great impediment for both the students and English teachers, as it was difficult to work with such large groups whose interests and needs differed to a great extent. Several trials with teaching materials referring to specialized disciplines stirred a great interest among the students which prompted the management of the School to make the decision to organize language classes in a different manner in order to meet the needs of the students more efficiently. Starting with the school year of 2013/14, students of each study programme attend English language classes separately from other groups, and Business English course materials are combined with materials from each specific field. This has already proven to be a good practice, as the students invest more in learning what they will actually be able to apply in their future professional lives.

However, as argued in the previous sections of this paper, these ESP courses could be made more efficient through collaboration with subject specialists. To exemplify this notion, we will outline a hybrid course of ESP for Computer Programming in the framework of the Computing and Informatics curriculum. The teacher of Computer Programming is an expert in their field, but is not required to know English, particularly at the level required for students; therefore, this cooperation would also help them to improve their language competences. As English language is closely tied to the specialized area of IT, collaboration among the faculty members could result in deeper learning.

According to Barron's collaborative method (1992), the contribution of the subject specialist could be indispensable; at the design stage, they may suggest topics to be covered in ESP class and help design needs analysis, while during the course they may give tutorials or lectures, hold discussions, provide assistance in writing or help to assess the students' performance on a project. The crucial point in this collaboration is that the subject specialist determines the content, while the ESP teacher works on the underlying concepts and skills. The IT science is changing rapidly, with numerous parts, applications and processes developed on an almost daily basis. Therefore, the subject specialist could help with the increased awareness of the texts and areas to be included into the course materials. For example, several IT course books frequently mention floppy disks that were widely used several years ago, but are not used by modern computers today.

The fact that classes for the students of Computing and Informatics usually take place at the Computer Laboratories could additionally facilitate the teaching and learning process, as the teachers could show the described processes and features to students in practice, and the students and both teachers could participate in joint studies and Internet searches. The role of the English language teacher is to explain the structure and meaning of linguistic units in English (words, phrases, clauses and sentences), and the role of the Programming teacher would be to clarify the meaning of particular words (vocabulary) in order to avoid semantic differences that need to be explained by both correct use of the vocabulary from the lexicon, and the use of that vocabulary in language structures.
The application of Barron's third model (1992), the intervention, is realized in the virtual learning environment where the language and the content are interwoven. In addition, by applying the principles of Content and Language Integrated Learning (CLIL), where the content is delivered in the foreign language, the virtual classroom changes the dynamics of the course into one which is "learner-centered, constructivist and motivating, as it prompts learners to use the language authentically to access information, gain understanding and formulate new content knowledge" (Ting, 2010). Additionally, the CLIL research suggests that providing curriculum content in a second or foreign language can lead to the enhanced L2 proficiency in the academic faculty (Brinton \&Snow, 1990). The synergy between the content and the language is embodied in the virtual classroom which creates a simulated reality for the language use in the context of the discipline (Fig. 1). The language, as well as the ESP teacher, depends entirely on the content component of this ensemble.

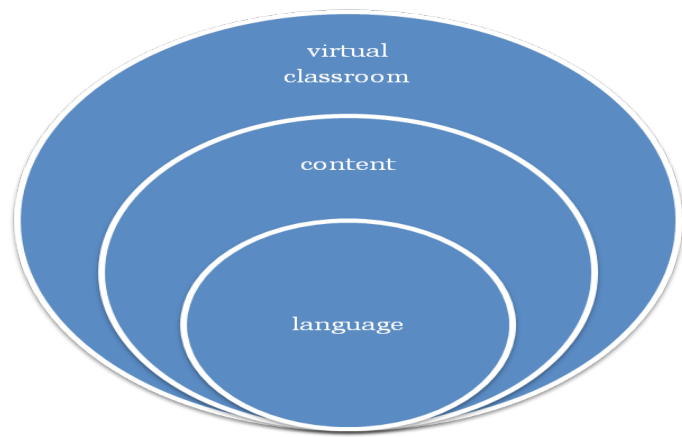

Fig. 1: How language and content intertwine

The hybrid model gives both teachers the extension of the structured learning time as well as the opportunity to plan more collaborative project or task based learning activities (Bonakdarian at al., 2010). For the purpose of this paper, we will follow Friends' concept of hybrid learning as “... a course that uses both in person and online instruction modes ... whatever delivery mode is most appropriate for whatever task needs to be accomplished" (2013).

The winning game plan in this model course lies in the combined learning outcomes for the online component, which cover language, content, and learning goals (Fig. 2). The activities and assignments in the virtual classroom reflect the combined learning outcomes. Hence, the areas of assessment are aligned to fit them both (Marsh, 2002):

- Achievement of content and language goals

- Achievement of learning skills goals

- Use of language for various purposes

- Ability to work with authentic materials

- Level of engagement

- Partner and group work

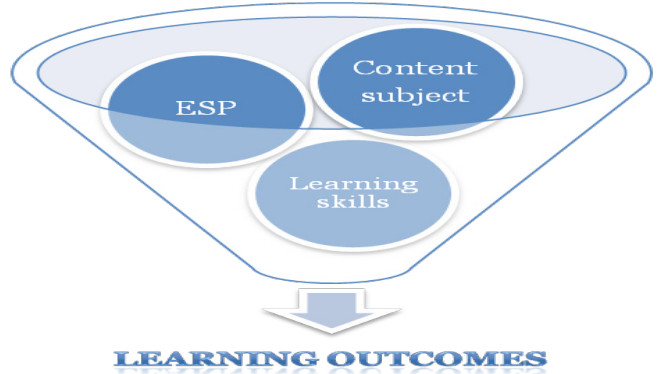

Fig. 2 Combined learning outcomes for the online component of the course 
The aforementioned strategies are obviously less problematic in teaching the Computing and Informatics students. However, they are applicable to other study programs, in which ESP teachers are working on adjusting teaching materials and combining texts from the field of Business English with texts specializing in the primary disciplines. Successful teaching and learning process regarding the curriculum that gets more and more complex with every school year, requires interdisciplinary team effort, as well as students' hard work, as the most important objective of this process is for them to acquire academic and professional competences they could afterwards effectively implement in their professional practice.

\section{ROADBLOCKS AND HOW TO OUTFLANK THEM}

The surveyed authors all agree that team teaching requires great effort and time invested by the teachers. Tension and conflicts are not rare, so the challenge is to turn the table and use the conflict as a learning opportunity (Buckley, 2000). Dinitz et al. believe that our academic and professional development, our experiences, our habits and beliefs make us "ill-equipped for sharing a classroom" (1997). We are used to being in control and successful in our practice, whereas team teaching disturbs all that. Stewart and Perry insist on reflection being an integral part of the teaching practice, team-teaching even more so (2005). Admittedly, they also suggest that "our assumptions about teaching and learning often remain tacit" mostly because we are used to being enclosed in our own discipline and we may lack the words to justify what we do. Finally, the issue of increased workload for already overworked teachers who lead busy lives is a tall obstacle.

In conclusion, or as a solution, this issue of the specialist competences of the ESP teacher can begin to be resolved with the model we proposed. However, this model is not sustainable due to the reasons described above and eventually, ESP teachers will be on their own again. The next road sign for the poor ESP teacher comes from Anthony who advocates that teachers should assume the role of students in the ESP design, learning from the consulting specialists and the students themselves (2007). In the first place, team-teaching practice can be a form of teacher development programme (Stewart \& Perry, 2005). Secondly, with language learners now assuming the role of experts in a particular field, their motivation and contribution will boost. In the end, that is the common goal the interdisciplinary faculty should work toward.

\section{SUMMARY}

The paper tackles the issue of ESP course design for the tertiary education; more specifically, it explores the role and significance of content or professional knowledge of the ESP teacher in the design process. The general goal of the paper is to advocate professional and language competences as a means of boosting employability and mobility of students. In addition, the specific aim of the paper is to present a combination of teaching methods to overcome the aforementioned issues in the course design.

Firstly, the paper outlines the problem of ESP course design and defines the term "teacher content knowledge" as the pivot point. Secondly, it reviews relevant theory and research literature supporting the strategy of interdisciplinary team teaching in ESP courses for university students. Finally, it specifies the models of team teaching that the authors base their proposal on.
In the main part of the text, the authors propose a hybrid course of English for Computer Programming to be delivered at the Business School of Applied Studies in Blace. The ESP course infers that a subject specialist works together with the ESP teacher to plan and deliver the learning activities both faceto-face and online in the virtual classroom. In the first learning environment, the subject specialist has the role of an informant, while in the virtual learning environment, the teaching team works side-by-side instructing and evaluating students. The online component of the course unifies language and content through CLIL approach and combined learning outcomes.

Instead of the conclusion, the paper directs attention towards the disadvantages of the interdisciplinary team teaching strategy and the issues in the sustainability of the proposed model. However, the authors recommend that the model ESP course should be just the initial step in achieving the more permanent solution.

\section{REFERENCES}

Anthony, L. (2007). The teacher as student in ESP course design. Keynote address presented at the 2007 International Symposium on ESP \& Its Applications in Nursing and Medical English Education. Kaohsiung, Taiwan: Fooyin University.

Barron, C. (1992). Cultural Syntonicity: Co-operative Relationships between the ESP Unit and Other Departments. Hong Kong Papers in Linguistics and Language Learning, 15, 2-15.

Bell, D. (2002). Help! I've been asked to teach a class on ESP. IATEFL Newsletter, No. 169.

Bess, J.L., \& Associates (2000). Teaching alone teaching together. San Francisco: Jossey Bass.

Bonakdarian, E., Whittaker, T., \& Yang, Y. (2010). Mixing it up: more experiments in hybrid learning. Journal of Computing Sciences in Colleges, 25(4), 97-103.

Brinton, D., \& Snow, M.A. (1990). Content-based Language Instruction. New York: Newbury House.

Buckley, F.J. (2000). Team Teaching: What, Why and How. California: Sage Publications Inc.

Communique of the Conference of European Ministers Responsible for Higher Education (2009). Leuven and Louvain-laNeuve. Retrieved February 20, 2015, from http://europa.eu/ $\mathrm{rapid} /$ press-release_IP-09-675_en.html

Conderman, G. \& McCarty, B. (2003). Shared Insights from University Co-Teaching.Academic Exchange Quarterly Winter, 7(4), 23-27.

Dinitz, S., Drake, J., Gedeon, S., Kiedaisch, J., \&Mehrtens, C. (1997). The Odd Couples: Interdisciplinary Team Teaching. Language and Learning Across the Disciplines, 2(2): 29-42.

Dudley-Evans, T. (1998). Developments in English for Specific Purposes: A multi- disciplinary approach. Cambridge: Cambridge University Press.

Fenollera, M., Lorenzo, J., Goicoechea, I., \& Badoui, A. (2012). Interdisciplinary Team Teaching. In B. Katalinic (Ed.) DAAAM International Scientific Book 2012, pp. 585-600. Austria: DAAAM International.

Friend, C.R. (2013). On Vocabulary: "Blended Learning” vs. "Hybrid Pedagogy" [Web log post]. Thinking Allowed. Retrieved February 20, 2015, from http://chrisfriend.us/Blog/ files/blended-vs-hybrid.php

Górska-Poręcka, B. (2013). The role of teacher knowledge in ESP course design. Studies in Logic, Grammar and Rethoric, 34(47), 27-42. 
Kaur, S. (2007). ESP course design: Matching learner needs to aims. ESP World, 1(14), 6.

Leavitt, M.C. (2006). Team Teaching: Benefits and Challenges. Speaking of Teaching, 16(1).

Little, A. \&Hoel, A. (2011). Interdisciplinary Team Teaching: An Effective Method to Transform Student Attitudes. The Journal of Effective Teaching, 11(1), 36-44.

Marsh, D. (2002). CLIL/EMILE - The European Dimension. Actions, Trends and Foresight Potential. Strasbourg: European Commission.

Nunan, D. (1987). The Teacher as Curriculum Developer: An Investigation of Curriculum Processes within the Adult Migrant Education Program. Adelaide: National Curriculum Resource Centre.
Selinker, L. (1979). On the use of informants in discourse analysis and language for specialized purposes. International Review of Applied Linguistics in Language Teaching, 17 (3), 189215.

Stewart, T., \& Perry, B. (2005). Interdisciplinary Team Teaching as a Model for Teacher Development. TESL-EJ, 9(2), 1-17.

Ting, Y.L.T. (2010). CLIL Appeals to How the Brain Likes Its Information: Examples From CLIL-(Neuro)Science. International CLIL Research Journal, 1(3), 3-18. 